\title{
A Study of Economic and Ecological Strategies for Sustainable Development in Aceh, Indonesia
}

\author{
Iskandar Zulkarnaen ${ }^{1}$, Jumadil Saputra ${ }^{2 *}$, Fauzi Abdurrahman ${ }^{1}$, Ella Suzanna ${ }^{3}$ \\ ${ }^{I}$ Faculty of Political and Social Sciences, University of Malikussaleh, 24351 Lhokseumawe, Indonesia \\ ${ }^{2}$ School of Social and Economic Development, Universiti Malaysia Terengganu, 21030 Kuala Terengganu, Malaysia \\ ${ }^{3}$ Faculty of Medical, Department of Psychology, University of Malikussaleh, 24351 Lhokseumawe, Indonesia \\ *Corresponding author E-mail: jumadil.saputra@umt.edu.my
}

\begin{abstract}
The sustainable development becomes an inevitable paradigm today. It does not only concentrate on economic growth, but also pay attention to other issues on environmental sustainability such as justice, welfare, as well as the maintenance of social and cultural systems. The sustainable development has some indicators and should also proceed with a series of stages namely economic, ecological, political and social culture. Using qualitative data analysis, this study is written to identify whether or not the economic and ecological development in Aceh post-tsunami has met standards of sustainable development. Troubleshooting analysis is performed with statistical studies of a variety of documents compared to some facts and the evolving dynamics in the community that were recorded by media. Based on the central of statistics bureau, Aceh is one of the regions with the highest GDP in Indonesia and there are approximately 6 million hectares of forest and also rich in nature and marine resources. The result of this study shows Acehnese people actually trapped in poverty. It is very ironic because the majority of people are living in the location of natural resources such as forests and coastal areas, as well as natural gas industrial areas. Therefore, the Aceh Government should ensure the welfare of Acehnese people through an optimizing the utilization of the natural resources i.e. forest and coastal and also gas industry.
\end{abstract}

Keywords: Sustainability; Developments; Ecological and economic.

\section{Introduction}

The province of Aceh covers sixth million hectares of forest area and widespread of sea access. Aceh is well known as one of the rice bowl provinces in Indonesia. Besides that, Aceh is rich with the mineral resources such as oil and gas have been proven by the presence of giant international oil companies namely Exxon Mobil, Medco, and some other mining companies. Further, Aceh is also blessed with fertile areas which are prospectively potential for agriculture industry such as palm oil, rubber, coffee, cacao, and clove, are some of the plantation features in Aceh. Further, in such a given situation, Acehnese should be one of the most prosperous society in the country.

After the tsunami and peace treaty, Aceh received huge money influx which enables the government to rebuild Aceh from the damage caused by both the conflict and natural disaster. The excombatants received compensation fund and two hectares of land to start their new piece of life as a normal society. Similarly, the tsunami victims also received rehabilitation support such as new housing and livelihood support from government and humanitarian aids agencies. However, in reality, the aids-based development failed in improving the Acehnese welfare. This condition creates questions such as how the actual concept of development applies in Aceh. Is it using the pro-growth concept without considering welfare, justice, and social stability and is the government of Aceh applies the concept of sustainable development?

The sustainable development is a concept of development that integrates all sectors either economic, social politic and environment that emphasized the sustainability of growth and welfare
[23]. Each sector has its own success indicators. To conclude, a sustainable development will not detriment one sector over the others, respect human rights, environmentally friendly and ensure sustainability. Based on the previous discussion above, this study is written to investigate the development process implemented by the Aceh government, especially in term of economic development and ecology preservation are already within the sustainable development paradigm.

\section{Literature Review}

The concept of sustainable development actually has long been a concern of experts [24]. The concept intensified discussed by previous research [13]. He argued that economic growth will be limited by the availability of natural resources. Despite criticism from economists due to weak economic approach in the concept, he had successfully brought new consciousness about the significance of sustainable development.

Until the 1980s the theory and practice of development are dominated by the paradigm of the Neo-classical pursuit of economic growth (economic growth). Approach or philosophy of this growth is dichotomous, because: first, it takes into account the efficient use of capital, labor, and high technology orientation, but on the second thought, the declining natural resources and environmental damage are not taken into account in the Accounting Matrix of Development. The impact of the application of this philosophy has led to rampant poverty, the destruction of ecosystems, pollution, and even a threat to human existence and humanity [15]. 
Besides that, it argued that the negative effect of economic growth, particularly environmental degradation, triggered the emerging of environmentalist groups that voiced the concern about the environmental damage impacted by excessive exploitation in the name of development [16]. They started thinking about a new concept and strategy of a development that able to boost economic and at the same time preserving the environment. By then, a new paradigm recognized as sustainable development has been introduced and been acknowledged [1-20].

The United Nations Environment Programme (UNEP) and the International Union for Conservation of Nature and Natural Resources (IUCN) and World Wide Fund for Nature (WWF) officially introduced this concept in the World Conservation Strategy published in 1980. Subsequently, in 1982, UNEP organized a special session commemorating the 10 years of the world's environmental movement in Nairobi, Kenya. The meeting agreed on the establishment of the World Commission on Environment and Development (WCED). According to the WCED, "Sustainable development is a development that meets the needs of present generations without compromising the ability of future generations to meet their own needs" [21].

The development concept is becoming increasingly complex, not only limited to the issues of economic growth but also included social and environmental issues [5]. Set apart from the general development paradigm, sustainable development claimed to be able to bring harmony between development and the environment [2]. In the beginning, the concept of sustainable development was only concerned with environmental or ecological issues. However, the concept evolved in which the sustainable development did not only focus on environmental issues but also covered three inter complementary policies: economic development, social development and environmental protection [8-15].

The concept of sustainability contained at least two dimensions: First is the dimension of time in which sustainability relates to what will happen in the future [10]. The second is the dimension of the interaction between the economic system and the system of natural resources and the environment. It stated that the sustainability assumption was based on three basic axioms: (i) the treatment of the present and the future that puts a positive value in the long term; (ii) recognizing that environmental assets contributing to economic wellbeing; and (iii) knowing the constraints due to the implications arising from the environmental assets [12].

Ideally, the three dimensions of sustainable development (economic, social and environment) can jointly operate and become a driving force in sustainable development. However, in reality, it is hard for developing countries to integrate the three pillars in the development process and thus the main focus is still on economic growth [15]. It stated that to achieve a sustainable development, a country must go through several stages by prioritizing sustainable aspects although the economic growth constantly targeted in each of the stages (i) the first stage focuses on the ecological balance; (ii) the second phase begins to focus on social welfare; (iii) third phase is to promote political participation of the local community [19]. These stages are described as the evolution of the concept of sustainable development, as in Table 1.

Table 1: The Evolution Stage for the Concept of Sustainable Development

\begin{tabular}{|c|c|c|c|}
\hline \multirow{2}{*}{ Pre Sustainable Development } & \multicolumn{3}{|c|}{ Sustainable Development } \\
\cline { 2 - 4 } & Phase 1 & Phase 2 & Phase 3 \\
\hline Economic Productivity (Growth) & Economic Productivity & Economic Productivity & Economic Productivity \\
\hline & Ecological Sustainability & Social Justice & Social Justinabe \\
\hline & & & Political Participation \\
\hline $\begin{array}{c}\text { As the main objective of } \\
\text { development }\end{array}$ & $\begin{array}{c}\text { Need to be reached and balanced } \\
\text { out in development }\end{array}$ & $\begin{array}{c}\text { Need to be reached and balanced } \\
\text { out in development }\end{array}$ & $\begin{array}{c}\text { Need to be reached and } \\
\text { balanced out in development }\end{array}$ \\
\hline
\end{tabular}

\section{Methodology}

This study used qualitative data analysis through library research. The relevant literature including journals, magazines, books, and other documents was used as primary and secondary resources Three phases were assigned in this study i.e. research preparation; document review, data analysis, and reporting the result. The research preparation included developing a research framework, defining data collection strategy and identifying key resources needed for the research. The second phase was a document review where researchers collected relevant data and investigated all available resources related to the research topic. The result of the library research and resource investigation was then accumulated for analysis and triangulation. The last phase was reporting in which all analytical data was being arranged in an academic writing format including the interpretation, explanation, and conclusion made by the researchers based on supported data and findings.

\section{Results and Discussion}

In sustainable development, the economic growth indicator should correspond to social change, environmentally safe and ensure the sustainability of welfare for the next generation. This is what is expected to be happening in Aceh. Some indicators can be used to evaluate whether the government of Aceh has applied the sustainable development concept in the economic and ecology strategy. Those indicators are:

\subsection{Economic Growth and Gross Domestic Product (GDP)}

Office of provincial statistic reported that GDP of Aceh from the year 2009-2012 increased in parallel with population growth. During the year 2012, the GDP per-capita was IDR. 20, 35 million. About 1, 21 million higher than GDP per-capita in 2011 (IDR. 19, 14 million). Based on GDP, Aceh listed as the fourth highest GDP of 34 provinces in Indonesia (see Table 1). Surprisingly, even during the conflict in 1999, Aceh listed as the fifth highest GDP in the country.

In general, the economic growth in Aceh showed a promising progress. During the period of 2009-2012, the economic growth of Aceh was constantly positive. Better infrastructure and the smooth flow of goods and services increased the price of domestic products. Meanwhile, the inflation rate significantly decreased from 3.43 percent in 2011 down to 0.22 percent in 2012 . Correction of the inflation rate was mainly contributed by the improvement in Banda Aceh and Lhokseumawe city.

Although the economic growth in Aceh was still below national average (6.23 percent in 2012), the economy of Aceh achieved 6.06 percent growth excluding the contribution from oil and gas which contributed about 2.74 percent in $2010,5.09$ percent in 2011 and up to 5.20 percent in 2012. The structure of the Aceh's GDP and ADHB in 2012 was significantly contributed by two sectors namely agriculture 27.03 percent and trade 16.83 percent. The next major contribution was transportation and communication 11.19 percent (BPS, 2013). In 2013, Aceh achieved 5.7 percent economic growth and therefore an estimated 6.3 percent growth in 2014 . 
Table 2: The Comparison of Economic Growth among Province in Indonesia (1978 - 2008)

\begin{tabular}{|c|c|c|c|c|c|c|c|c|}
\hline \multirow{2}{*}{ Province } & \multicolumn{2}{|c|}{1978} & \multicolumn{2}{|c|}{2008} & \multicolumn{2}{|c|}{1999} & \multicolumn{2}{|c|}{2007} \\
\hline & GDP & Rank & GDP & Rank & GDP & Rank & GDP & Rank \\
\hline Nanggroe Aceh Darussalam & 188 & 6 & 1,910 & 4 & 6,864 & 5 & 17,329 & 7 \\
\hline Sumatera Utara & 167 & 9 & 808 & 9 & 5,476 & 6 & 14,167 & 11 \\
\hline DKI Jakarta & 331 & 4 & 2,150 & 3 & 19,767 & 2 & 62,490 & 2 \\
\hline Jawa Tengah & 95 & 23 & 591 & 17 & 3,317 & 19 & 9,469 & 21 \\
\hline Kalimantan Timur & 1,246 & 1 & 4,672 & 1 & 23,640 & 1 & 70,120 & 1 \\
\hline Nusa Tenggara Timur & 73 & 26 & 299 & 25 & 1,456 & 27 & 4,302 & 32 \\
\hline Papua & 363 & 3 & 856 & 6 & 8,913 & 4 & 27,468 & 5 \\
\hline Sumatera & \multicolumn{2}{|c|}{227} & \multicolumn{2}{|c|}{1,053} & \multicolumn{2}{|c|}{ 5,455 } & \multicolumn{2}{|c|}{-} \\
\hline Indonesia & \multicolumn{2}{|c|}{153} & \multicolumn{2}{|c|}{816} & \multicolumn{2}{|c|}{5,040} & \multicolumn{2}{|c|}{17,581} \\
\hline
\end{tabular}

Although the economy had grown it was not as fast as expressed by the statistics. Over the years, the largest contribution came from the oil and gas industry. Ironically, in addition to emerging as one of the richest provinces in Indonesia, Aceh was also one of the poorest. In 2008, the position of Aceh was just a bit better than Papua. Improvement in economic sector actually was contributed by the large scale of post-tsunami recovery programs, which created job opportunities with better wages. The influx of fund invested in Aceh during the recovery program triggered a temporary boost to the economy, but most of the program had ended.

As a region with abundant natural resources, Aceh's economic growth was driven by oil and gas. Consequently, the declining reserves followed with the unstable price of oil and gas affected the growth in Aceh. Nowadays, the revenue from oil and gas was constantly decreasing while, on the contrary, the revenue from non-oil and gas sector continued to increase. Based on the reality, the assumption that the economic growth in Aceh would reach 6.3 percent in 2014 was unrealistic. The Central Statistics Agency of Aceh Province recorded economic growth in the province which continued to decline. In the second quarter of 2014, oil and gas only contributed 0.97 percent while the non-oil and gas contribution reached 1.32 percent growth.

Earlier, in the first quarter 2014 economic growth in Aceh had dropped to its lowest level since experienced a negative growth of -0.20 percent in the first quarter of 2014 , lower compared to growth of the fourth quarter-2013 which reached 1.41 percent. By excluding the oil and gas, growth was also negative and fell deeper amounting to -0.37 percent. This was different from previous quarters, in which the growth of the oil and gas usually was always lower than non-oil GDP growth. In the first quarter of 2014, there were only 3 sectors contributed to positive growth: agriculture grew as of 0.76 percent, mining and quarrying grew as of 0.60 percent while manufacturing sector experienced the highest growth as of 2.36 percent. Six sectors experienced negative growth namely electricity, gas and water supply fell as of 2.26 percent, the property fell as of 1.88 percent, trade, hotels, and restaurants fell as of 1.02 percent. Transportation, communications, finance, building rental, and services were also declined.

Negative reaction to the economic stagnant was undeniable. Civil society groups were beginning to voice their dissatisfaction and demanded the Governor of Aceh Mr. Zaini Abdullah to resign from office. Zaini considered incapable to improve the welfare of the Acehnese. People couldn't understand the ironic fact that the abundant fund had not contributed to economic growth and welfare. The governor was also considered not able to fulfill his promise during the campaign though it was outlined in the Medium Term Development Plan. The Aceh Provincial Government was accused to be busy with minor issues such as a provincial flag, emblem and political image.

Natural resources have limitations and can only survive for a limited period. The best strategy for regional economic development is an investment. However, the investment is the main bottleneck in Aceh. According to the report released by the World Bank, one of the barriers to economic growth in Aceh is the lack of electricity. The second problem is bribery. In the meantime, financial institutions such as bank are also reluctant to provide loan for small and medium enterprises. The other problem is the inclusion of an unprofessional group who won the tender on infrastructure projects in Aceh. Not to mention the problem of the weakness of political communication between Aceh and the central government. Another setback in Aceh economic decline is the weak performance of the executive which makes the mission and expectations of the Governor Zaini Abdullah has not achieved satisfactory results.

\subsection{Employment and Unemployment}

Unemployment, according to Provincial Statistic Agency (PSA) is a group of people who do not work. Unemployment is caused by two things. First, the labor force continued to increase in number and the growth of employment is not balanced with the growth of the workforce. Second, the labor force looking for work does not meet the requirements demanded by the market. The concept of employment in Indonesia known as the term of the labor force, i.e. the working age population between 15 years to 65 years, who work or have a job but temporarily absent from work and those who are not working but looking for work.

The unemployment rate in Aceh tended to fall from 2009 to 2010 both in number and percentage. The District of North Aceh was the region with the highest unemployment, wherein 2010 the number of unemployed people reached 27.417 people. The fewest number of the unemployment rate was in the City of Subulussalam which only 949 people in 2010 . In terms of percentage, in 2010, the City of Langsa had the highest unemployment rate (12.95 percent) and the lowest was in the District of Bener Meriah (2.25 percent)

However, based on PSA data released in 2012, the labor force in Aceh was about 1,978,491 people with an unemployment rate of 179.944 people or 9.10 percent. The previous year, the number of workforce in Aceh reached about 2.001.259 people with unemployment rate amounted to 148.786 people or 7.43 percent. This means the number and percentage of unemployment in Aceh increased by 1.66 percent.

Based on statistical data, the figure of unemployment in Aceh was constantly increasing. In 2011 the number of unemployed people reached about 150,000 people. In 2012 increased up to 180,000 people. In 2013, the number of unemployed persons also increased about 30.000 persons that pushed the number up to 210,000 people. If the upward trend continues to be consistent, then this means that the number of unemployed persons in Aceh would possibly reach 240.000 to 250.000 people in 2014 .

What is the actual number of unemployment in Aceh? Based on the PSA data above, the number is still debatable. There is a possibility that the unemployment number in Aceh is much higher than the number presented. This is due to the high rate of informal workers nationwide. It is still undecided for people working within the informal sector: are they considered as a worker or unemployed? Yet for sure, the informal workers are the one with low salary and with the highest working risk. Some even do not have a safe working contract, including social protection or labor union [3]. Fact is, there are used to be six out of ten workers in Aceh 
who work in informal sectors. However, the number has increased up to four out of five workers in Central Aceh within the informal sector.

In addition to indefinite sector criteria or work area, the low level of unemployment in Aceh is because the PSA is giving a loose definition of the worker. If someone within workable age working for one hour in a week, then he is considered as "not unemployed" even though he has low productivity [17]. In 2012, the PSA Aceh stated the unemployment rate as of 9,10 percent which defines the open unemployment rate or actual unemployed people.

The issue of the labor force is not only open unemployment but also subtle unemployment or underemployment. Outside the unemployed with such qualifications, Aceh still has a large number of unemployed in the economic concepts included in the qualification of disguised employment and underemployment. Underemployment is a work that does not optimally because they do not get a job within their expertise or their wishes due to weak labor demand. Meanwhile, the underemployment is a labor force whose working hours is limited due to the lack of opportunity [17].

This unemployment symptom is a threat toward Aceh economy and needs to be taken seriously by the local government. The high unemployment reflects the drop level of prosperity. Unemployment is also a threat to economic growth as many people will not have income. Lack of income means lack of demand for goods and services, which threatens the growth stagnation or lethargy. Unemployment also threatens state revenue for the low government's ability to collect taxes due to low income. In addition to economic issues, unemployment also bred a social threat because of the increasing number of the poor and the increasing rate of crimes that may arise or increase in illegal economic activities such as smuggled goods. In many cases, besides having social problems, poverty issues always have an impact on political power. One of the reasons behind turmoil and instability in the Aceh region is the economic problem, where one indicator is the high unemployment rate. Psychologically, unemployment will affect the community itself because they feel useless and received a negative view of society.

\subsection{Poverty}

Poverty is a multidimensional concept of human welfare that includes many traditional measures of prosperity, such as income, health, and safety. Poverty in Aceh is an acute chronic symptom that continues to haunt. This occurs because Aceh has long trapped in a protracted conflict that makes people busy with security issues rather than welfare. Moreover, Aceh's natural resources are not always benefited from the Aceh people welfare. It makes the average or the percentage of poverty in the province is always higher than the average or the national poverty percentage.

Poverty increased after the tsunami and then the earthquake or flood came and went sometime later ravaged the goods and wealth of the people of Aceh. It is poverty which marks the increased level of crime or criminality in Aceh up to 372 percent one year after the peace [7]. Thousands of Acehnese were forced to become refugees and some of them are still inhabiting the make-shift barracks where three families can live in a room measuring $4 \times 5$ meters without sanitation and water for months.

The success of development in Aceh is also expected to influence poverty reduction in the regions. In 2010 the poverty rate in Aceh amounted to 19.95 percent. Among the 23 regions in Aceh, 11 regions had poverty rates lower than the provincial Human Development Index (HDI). The eleventh area was Southwest Aceh, Bireuen, Aceh Singkil, Aceh Besar, East Aceh, Aceh Tamiang, Aceh Tenggara, South Aceh, Kota Langsa, Kota Lhokseumawe, and Banda Aceh. The highest poverty rate was in Bener Meriah which was 26.23 percent and the lowest poverty rate was in Banda Aceh which was 9.19 percent. The Aceh government gradually succeeded in reducing poverty and the percentage was decreasing from year to year. Until 2013, the number of poor people in Aceh was 17.60 percent, a decrease from previous years (see Table 2). The 2014 estimated poverty rate also decreased.

Table 3: Percentage of Poor People in the Urban and Rural Area at Aceh (1999-2013)

\begin{tabular}{|c|c|c|c|}
\hline Year & City & Village & Total \\
\hline 1999 & 10,15 & 16,30 & 14,75 \\
\hline 2000 & 10,45 & 16,78 & 15,20 \\
\hline 2001 & 13,03 & 20,92 & 19,20 \\
\hline 2002 & 20,09 & 33,06 & 29,83 \\
\hline 2003 & 19,47 & 33,63 & 29,76 \\
\hline 2004 & 17,49 & 32,57 & 28,37 \\
\hline 2005 & 19,04 & 32,60 & 28,69 \\
\hline 2006 & 19,22 & 31,98 & 28,28 \\
\hline 2007 & 18,68 & 29,87 & 26,65 \\
\hline 2008 & 16,67 & 26,30 & 23,53 \\
\hline 2009 & 15,44 & 24,37 & 21,80 \\
\hline 2010 & 14,65 & 23,54 & 20,98 \\
\hline 2011 & 13,69 & 21,87 & 19,57 \\
\hline 2012 & 13,07 & 21,97 & 19,46 \\
\hline 2013 & 11,59 & 19,96 & 17,60 \\
\hline
\end{tabular}

Overall, according to BAPPEDA, the percentage of poverty in the province was 17.6 percent. With this data, Aceh held the "third" position nationally in terms of poverty. The data showed that poverty in Aceh was high and the people of Aceh were still far from prosperous. The high number was triggered by slow economic growth. From year to year, the allocation of Provincial Budget (APBA) was increasing without significant improvement in the economic sector. On the contrary, the poverty rate was getting higher as well as the crime rate.

Then, what exactly is poverty? This question seems so simple but it requires a variety of answers and theories or perspectives to explain it. Poverty is simply defined as the difficulty to meet the basic living needs or to improve the situation of not having a decent job and resulting on the loss of self-esteem, dependency, forced to accept the harsh treatment, and ignored when looking for help. Poverty can be caused by the scarcity of means of fulfilling basic needs or the difficulty of access to education and employment.

PSA consistently considers that the poverty measure is seen as the inability of a person to meet basic needs. For example, food and non-food basic needs. Actual poverty is not only viewed from economics and sheer material aspects but also can be seen from the social, cultural, institutional and structural dimension. Therefore, poverty is often linked to (i) individual causes, or pathological, which sees poverty as a result of the behavior, choices, or the ability of the poor; (ii) family causes, linking poverty with education family; (iii) sub-cultural causes, linking poverty with daily life, learned or run in the neighborhood; (iv) Agency causes, which see poverty as a result of the actions of others, including war, government, and economics; (v) structural causes, which argue that poverty is the result of the social structure.

Poverty can be categorized into two categories, namely absolute poverty, and relative poverty or medium. Absolute poverty refers to a set of consistent standards, unaffected by time and place/country. An example of an absolute measurement is the percentage of the population who eat under a sufficient amount to sustain the needs of the human body (approximately 2000-2500 calories per day for adult men).

The World Bank defines absolute poverty as living on less than USD $\$ 1 /$ day and relative poverty as to live with income of less than $\$ 2$ per day, with this limit then it was estimated in 2001 that 1.1 billion people worldwide consumed less than $\$ 1 /$ day and 2.7 billion people the world consumed less than $\$ 2$ / day. The proportion of people in developing countries living in extreme poverty had fallen from 28 percent in 1990 to 21 percent in 2001. Looking at the period from 1981 to 2001, the percentage of the world's population living below the poverty line of $\$ 1$ dollar/day had been reduced by half. However, the value of $\$ 1$ was also declined during the period. 
Based on the GDP indicator per capita, Aceh was one of the rich provinces in Indonesia, yet the expenditure per capita shows that the people of Aceh were among the poorest. In 2008, the average expenditure per capita in Aceh was below average among the cities. The lowest household expenditure was in Aceh Tengah, while the highest - although only 8 percent - were in the Aceh Barat and Aceh Selatan.

Aceh as areas with severe poverty is not only happening at the present time when the growth of Aceh is very low but also occurred during the high growth. This suggests that economic growth is not always positively correlated with the level of welfare. Economic growth should help create opportunities to earn a living and reduce poverty, but its impact in Aceh was weak. In 2008, Poverty Needs Assessment Study in Aceh showed that growth was giving weaker impact compare to other regions in Indonesia. PSA and World Bank estimation stated that despite an increase of 1 percent in economic growth elsewhere in Indonesia to reduce poverty by 3 percent, the increase reached less than half in Aceh. PSA counted those who categorized as absolute poverty measured by income as the most minimal standards. It is also based on the minimum health standards in which each person requires a minimum 2,100 calories per day. Nationally, $2,100 \mathrm{kcal}$ was equivalent to 5,000 per day per capita plus non-food requirements which consist of health, education, and transport. Thus the measurement standard used is IDR 7,050 per day. This means that a resident who earns more than IDR. 220,000 per month is classified as not poor. The measurement used for poverty by PSA arises questions. The PSA poverty indicators are suspected to reduce the number of poor people. The goal is politically motivated to project a positive image of the government in reducing the poverty rate.

With the given standard, it is understandable if the number of poor people in Aceh is relatively low. For even public transportation drivers, street vendors or even pedicab riders are able to generate net income of IDR 20,000 per day. A beggar in Aceh was able to stay at a hotel with the rate of IDR 75,000 per day. But, they are not prosperous people and are a vulnerable group. These figures do not reveal the real face of poverty dimension in Aceh. If we are using the standard income USD 2 per day, the number of poor people in Aceh will dramatically double in number.

\subsection{Environmental Conservation}

The paradigm of sustainable development in its spatial planning should create a comfortable environment for the populations, where the economic and socio-cultural access should facilitate every citizen to meet their basic needs, social interaction and environmental friendly. Spatial planning is one of the policies needed to guarantee the continuity of the process of sustainable development.

Post-tsunami 24 December 2004, Aceh experienced a rapid development due to financial influx into the region. From 2006 until the end of 2013, Aceh received a budget of more than IDR 100 trillion. Infrastructure development was further boosted by the endorsement of Law no. 11 regarding Aceh Governance in the year 2011 Unfortunately, the focus of development was very much emphasized on infrastructure and pays less attention to ecological sustainability, exploitative and lack of law enforcement regarding environmental conservation.

Until 2012, the Aceh government successfully developed more than 20 regulations such as legislation and governor decree related to environmental management in Aceh. However, the available regulations were not supported by law enforcement while the development activities disregard the environmental preservation. Wahana Lingkungan Hidup Indonesia (WALHI), a national NGO, has repeatedly warned the government for the potential threat of ecological disaster due to improper development. The unstable soil structure followed by weak supervision of building construction and massive destruction of the forest visibly exacerbates environmental degradation in Aceh.
Since 2005, post-tsunami disaster, Aceh is well known as a disaster prone area. Based on data recorded by Aceh's Geophysics Station, during 2012 alone, Aceh experienced 2,290 earthquakes in which 19 of them were strongly felt by inhabitants. In addition to the earthquake, Aceh is also often hit by ecological disasters such as floods, forest fires, and landslides. Those ecological disasters caused severe damage to the environment. Environmental damage continues to occur as a result of lack of attention to environmental aspects. Irregularities in local administration such as corruption, lack of transparency and lack of public participation, such as in Environmental Impact Assessment, had significantly contributed to the environmental problem. In Aceh Jaya for example, the community is threatened by mercury contamination due to unregulated traditional gold mining.

\subsection{Development with Respect to Environment and Lo- cal Wisdom}

Development in Aceh regulates by Provincial Regulation (Qanun) No. 19 the year 2013 regarding Spatial Planning (RTRW) of Aceh. However, the Qanun triggered wide critics from the public as the regulation seems threatening the environment instead of preserving the environmental sustainability. This is visible in the case of the protected area of Leuser Ecosystem Area (KEL) which has been made uncertain in the Qanun. The elimination of KEL will badly impact on Indonesia's commitment to reduce carbon emissions and reflect the lack of disaster awareness within the policymakers.

Forest plays an important role in global climate. Scientist generally agreed that the increase and concentration of carbon dioxide $(\mathrm{CO} 2)$ in the atmosphere is one of the contributors for global climate change. In regard to forestry management, Aceh already has Qanun No. 14 the year 2002 Regarding Forestry in Aceh. However, the community considers the Qanun as ineffective and does not able to prevent the destruction of forests and environment in Aceh. The Qanun contains 21 points of a delegation of authorities by the governor to major at district level which could potentially trigger corruption.

Forest area in Aceh Province according to Minister of Forestry Decree No: 170 / Kpts-II / 2000 dated June 29 the year 2000 on the Designation of Forest Areas and Water of Aceh Province consist of 3,549,813 ha. Unfortunately, the forests of Aceh over the years has always been deforested and degraded. One of the contributors is the poor administrative management related to permission for Utilization License Timber Forest Products in Natural Forest (IUPHHKHA - used to be called HPH).

Deforestation also triggered by illegal logging activities. In 2006, there were approximately $120,209.50 \mathrm{~m}^{3}$ of timber from illegal logging confiscated. This figure has increased four-fold from the previous year, which is around $33249.25 \mathrm{~m}^{3}$. On June 6,2007 , the government has issued a moratorium on logging, but in practice, illegal logging continues to occur behind the scene.

Based on data from TIPERESKA (Task Force) released in 2008, the Aceh's forest in 1945 was about 4,908,019 ha but then reduced to $4,085,741$ ha in 1980 or loss of forest area of about 822278 ha in ten years. Thus, the rate of forest destruction in the period was 23.494 ha per year. Referring to the results of the Strategic Environmental Assessment (SEA) by Aceh's Agency of Environmental Impact Control (BAPEDAL) in 2013, the rate of deforestation in Aceh continues to increase every year. The rate of forest destruction in all districts/cities in Aceh is quite high which reached an average of 23124.39 ha/year.

The impact of deforestation and forest degradation provides a double effect (multiplier effect), especially in the province of Aceh. Some of the impacts are on the direct losses cause by disasters such as floods and landslides as well as forest fires. The impact does not only threaten the lives of the surrounding communities but also affects the social and economic stability in the province. In the last 10 years, the losses contributed by floods and 
landslides approximately reach IDR 800 billion of the provincial budget.

\section{Conclusion}

Aceh has approximately 6 million hectares of forest area and has 2,666.27 kilometers coastline. From the economic perspective, the forest and sea are considered as natural resources. But ironically, the people who live near the forests and sea are mostly poor. This is a result of poor development concept in Aceh, particularly in the context of economic development and ecological sustainability which are not applying the sustainable development approach. Sustainable development requires serious attention by the government to implement an economic policy that is environmentally for the people's welfare.

Economically, Aceh experienced low economic growth while at the same time environmental degradation is high. The equilibrium between economic productivity and ecological sustainability are not yet a practice in Aceh. The same anomaly also occurs if we look at the income status where Aceh is enjoying the influx of fund from post-tsunami reconstruction and special autonomy fund but ironically Aceh has been ranked as one of the poorest provinces in the country. Correspond to that, Aceh also listed as the worse province in the corruption index.

Based on this study, some priority sections that need to be considered to reduce the poverty in the province have been identified. Firstly, the long-term development strategy should focus on the poorest areas in Aceh, especially the rural areas. Secondly, poverty reduction strategy should focus on increasing the productivity of agriculture and fisheries sectors. Thirdly, to prevent irregularities, it is necessary to increase the transparency of the distribution and utilization of revenues and strengthen law enforcement. Fourthly, the government of Aceh should continue the strategic investment in the education sector, improving the efficiency of spending. Special attention should be given to higher education that closely linked to poverty reduction strategy in Aceh.

Policy reform is a must for sustainable development in Aceh, both targeting economic growth and environmental sustainability. In the economic sector, one of the focuses must be the empowerment of the vulnerable group. In addition, improvement of economic facilities and infrastructure is needed to support productivity including the maritime sector. The government also needs to develop a comprehensive strategy and actions to address poverty and unemployment. One of the recommendations is to facilitate better access to financial institutions for the Small and Medium Enterprises (SME) and another informal sector. The SME and informal sector have been proven to be resilient and played an important role during the economic crisis in 1997-1998. One of the factors inhibiting the growth of formal sector employment in Aceh is the high standard of a minimum wage set by the provincial government, which is the highest minimum wage in Indonesia

It is important to note that the poverty reduction strategy must not pursue growth at the expense of the environment. While the use of natural resources such as wood, sand, and rocks is needed for reconstruction, special attention should be given to ensuring that such exploitation activities do not result in illegal logging or the destruction of the environment. The negative environmental impacts of infrastructure and housing activities on natural resources and environment should be evaluated and minimized. There is a clear need for an integrated planning for economic and environment.

\section{References}

[1] Baker S. Theoretical and conceptual of sustainable development. Routledge, 2006.

[2] Barbier EB. Economics and ecology: New frontiers and sustainable development. Chapman and Hall, 1993.
[3] Basri F. Analisis ekonomi Faisal Basri: Kita harus berbenah. Kompas Media Nusantara, 2005.

[4] BPS Aceh. 2010-2013, Produk domestik regional Bruto menurut pengeluaran provinsi Aceh 2009-2012.

[5] Budiman A. Teori pembangunan dunia ketiga. PT Gramedia Pustaka Utama, 1995.

[6] Budimanta A. Memberlanjutkan pembangunan di perkotaan melalui pembangunan berkelanjutan dalam bunga rampai pembangunan kota di Indonesia dalam abad 21. Gramedia, 2005.

[7] Djalal HDSD. Seeking lasting peace in Aceh. CSIS, 2006.

[8] Djajadiningrat. Konsep pembangunan berkelanjutan dalam membangun tanpa merusak lingkungan. Kementerian Lingkungan Hidup, 1992

[9] Evans H. Laporan pembangunan manusia Aceh 2010. UNDP, 2011.

[10] Fauzi A. Ekonomi sumber daya alam dan lingkungan. PT. Gramedia Pustaka Utama, 2004.

[11] Kuper A, Kuper J. Ensiklopedi ilmu-ilmu sosial. Gramedia, 2000.

[12] Mawhinney M. Sustainable development: Understanding the green debate. Blackwell Publishers, 2002.

[13] Meadows DH, Dennis LM, Jorgen R, William WB. The limits to growth. In Green Planet Blues: Critical Perspectives on Global Environmental Politics. Routledge, 2018, pp. 25-29.

[14] Pearce DW, Turner RK. Economics of natural resources and the environment. Harvester Wheatsheaf, 1990.

[15] Pearce DW, Wardford JJ. World without end, economics, environment, and sustainable development. Oxford University Press, 1993.

[16] Pearce DW. Environmental economics. Prentice Hall Press, 2000.

[17] Prasetyanto AT. Rambu-rambu yang diabaikan. PT. Kompas Media Nusantara, 2005.

[18] Rivai RS, Iwan S. Konsep dan implementasi pembangunan berkelanjutan di Indonesia. PSEKP, 2011.

[19] Urban and Regional Development Institute (URDi). Bunga Rampai Pembangunan Kota Indonesia dalam Abad 21: Konsep dan Pendekatan Pembangunan Perkotaan di Indonesia. URDi, 2014.

[20] Sutikno, Maryunani. Ekonomi sumber daya alam. Badan Penerbit Fakultas Ekonomi Universitas Brawijaya, 2006.

[21] The United Nation. Report of the World Commission on environment and development our common future. The United Nation, 1987.

[22] UNESCO. Deklarasi keberagaman budaya. UNESCO, 2001

[23] Giddings B, Hopwood B, O'brien G. Environment, economy and society: Fitting them together into sustainable development. Sustainable Development, 2002, 10(4): 187-196.

[24] Lélé SM. Sustainable development: A critical review. World Development, 1991, 19(6): 607-621. 